\title{
Penkkiviljelytekniikan vaikutus multa- ja turvemaan lämpötilaan
}

Jussi Esala

Seinäjoen ammattikorkeakoulu, Maa- ja metsätalouden yksikkö, Ilmajoki

Ilmajoentie 525, 60800 ILMAJOKI

jussi.esala@seamk.fi

\section{Tiivistelmä}

Penkkiviljelytekniikan vaikutusta multa- ja turvemaan lämpötilaan tutkittiin Ilmajoella v. 1999 - 2003 järjestetyissä kenttäkokeissa. Käsittelyt olivat: tasainen maa (0), pieni kolmiopenkki (1), pieni tasalakinen penkki (2) ja suuri tasalakinen penkki (3). Kokeet perustettiin joka vuosi syyskynnetylle maalle. Koealue muokattiin 8 - $10 \mathrm{~cm}$ syvyyteen penkkien muotoilun helpottamiseksi ja jyrättiin ennen kylvöä. Penkit muotoilu tapahtui kylvölannoittimen eteen ja taakse asetettujen muotoilulevyjen avulla, ja tämän lisäksi vielä viimeistely käsiharavalla. Yhteensä 60 lämpötila-anturia sijoitettiin ruudun keskelle 7 ja 15 cm syvyyteen ja sivuille (1/4 kohta, penkit 2 ja 3) 7 cm syvyyteen. Lisäksi käsittelyissä 3 ja 4 oli yksi anturi 20 ja 30 cm syvyydessä ja yksi anturi asetettiin mittaamaan ilman lämpötilaa 1,5 m korkeuteen. Anturit kytkettiin dataloggeriin, joka mittasi lämpötilat 20 minuutin välein. Maan tuntikohtaisten lämpötilojen keskiarvo on kylvöhetkestä keltatuleentumisen ajankohtaan kestäneissä mittauksissa ollut penkkikäsittelyissä useimmiten hieman $\left(0,1-0,4{ }^{\circ} \mathrm{C}\right)$ korkeampi kuin tasaisella maalla. Lämpötilaero penkkien hyväksi on myös poikkeuksetta ollut $15 \mathrm{~cm}$ syvyydessä suurempi kuin $7 \mathrm{~cm}$ syvyydessä. Penkkityyppien välillä ei ollut eroa. Samoin vuosien väliset erot jäävät vähäisiksi. Anturien vähäisestä määrästä ja maan ominaisuuksien vaihtelusta johtuvan hajonnan vuoksi käsittelyjen väliset lämpötilaerot eivät ole tilastollisesti merkitseviä. Penkkien lämpötila nousee selvimmin tasaisen maan lämpötiloja suuremmaksi, jos aurinkoinen ja lämmin sää ajoittuu kasvukauden alkuun. Penkkien tasaista maata suurempi pinnan ala ja erityisesti pinnan suotuisa kulma tulosäteisiin nähden tehostaa lämmön siirtymistä maahan. Näin käy selkeimmin aamulla ja iltapäivällä, jolloin aurinko on paistanut penkkien sivuihin. Myös myöhemmin kasvukaudella lämpimät säät näkyvät penkkien ja tasaisen maan lämpötilaeroissa. Lämpimien säiden vallitessa heinäkuussa tutkimusvuosina 2001 - 2003 ovat erot olleet $0,2-0,7{ }^{\circ} \mathrm{C}$ penkkikäsittelyjen eduksi. Myös viileällä ja kuivalla säällä maan lämpötila on ollut penkeissä korkeampi kuin tasaisessa maassa, mutta erot ovat pienempiä kuin lämpimillä jaksoilla. Sen sijaan viileällä ja sateisella säällä penkkien lämpötilat ovat lähellä tasaisen maan lämpötiloja. Yhtä poikkeusta lukuun ottamatta ne ovat silti olleet korkeampia kuin tasaisessa maassa. Näillä viileillä kausilla, jolloin penkkien lämpötilaetu olisi ollut eniten tarpeen, on se jäänyt alhaisimmaksi. Lämpötilaeroilla ei ole kuitenkaan ollut muutamaa poikkeusta lukuun ottamatta tilastollista merkitsevyyttä, ja erojen käytännön merkittävyys jää pieneksi.

Asiasanat: turvemaat, lämpötila, muokkaus 


\section{Johdanto}

Kesäkauden ilman keskilämpötila vaihtelee Suomessa 11 - $15^{\circ} \mathrm{C}$ (YLI-HALLA 1998), ja lämpimimmän kuukaudenkin, heinäkuun, keskilämpötila jää miltei koko Suomessa alle $17{ }^{\circ} \mathrm{C}$. Kun viljojen kasvulle optimaaliset ilman ja maan lämpötilat ovat huomattavasti edellä esitettyjä korkeammat (mm. MAYER ja POLJAKOFF-MAYER 1989), on lämpötila merkittävä kasvua rajoittava tekijä maassamme. Tämä korostuu erityisesti multa- ja turvemailla, joiden osuus Suomen koko viljelypinta-alasta vaihtelee lääneittäin runsaasti kokonaisalan ollessa 300000 ha (MYLLYS ja SINKKONEN 2004).

Maan lämpötilaan vaikuttavat auringon paisteen seurauksena maan pinnalla vallitseva nettosäteilyn taso, maan ominaislämpökapasiteetti ja maan lämmönjohtavuus. Nettosäteily on pilvettömänä päivänä enimmillään n. $600 \mathrm{~W} / \mathrm{m}^{2}$ ja yöllä se on yleensä negatiivinen jopa $\mathrm{n} .-100 \mathrm{~W} / \mathrm{m}^{2}$ tasolla (HANKS 1990, s.108). Orgaanisen aineen lämmönjohtavuus on huono erityisesti kuivana (van DUIN 1963 ref. BAVER ym. 1972, s.273), mikä näkyy erityisesti turvemailla maan alhaisina lämpötiloina. Toisaalta hyvin kostean turvemaan korkea ominaislämpökapasiteetti estää tehokkaasti lämmön pääsyä syvempiin kerroksiin, mikä pitää maan keväällä pitkään kylmänä.

Maan muokkauksella kasvatetaan huokostilavuutta, mikä hidastaa lämpövirran liikettä muokkauskerroksessa (FEDDES 1973). Muokkaus lisää myös maan pinnan karkeutta, minkä seurauksena heijastuminen vähenee ja nettosäteily kasvaa (POTTERIN ym. 1987). Toisaalta tuulisissa oloissa maan pinnan karkeus lisää turbulenttisia pintavirtailuja, mikä voi jopa laskea maan lämpötilaa (ALLMARAS ym.1977, ref. SHARRATT 1996, POTTER ym. 1987). Muokkaukselle päinvastaisella toimella, jyräyksellä, tiivistetään pintakerrosta, mikä puolestaan pienentää maan lämpötilan vuorokausivaihtelua aivan pinnassa, mutta suurentaa syvemmällä (5 - $10 \mathrm{~cm}$, LIEPIEC ym. 1991), alentaa kylminä öinä hallariskiä (FEDDES 1973), suurentaa lämpövirtaa maahan ja nostaa maan juuristovyöhykkeen lämpötilaa (POTTER ym. 1987).

Penkkiviljelyllä pyritään parantamaan maan lämpöolosuhteita, erityisesti kasvukauden alussa orastumisvaiheessa. Myöhemmin kasvuston varjostus pienentää tai poistaa edun. Maan pinnan ala kasvaa penkeissä sitä suuremmaksi, mitä jyrkkämuotoisemmista penkeistä on kysymys. Suurentunut maan pinnan alalla tarjoa siten potentiaalia sekä vastaanottaa että myös ulossäteillä lämpöenergiaa enemmän kuin tasainen maa (POTTER ym. 1985). Samalla myös maan vuorokautinen lämpötila- ja lämpövirtavaihtelua lisääntyy. Päivän aikana tasaista maata enemmän lämmennyt penkki säteilee ulos yöaikaan tasaista maata enemmän ja myös jäähtyy enemmän. Ilmiö on vahvistettu sekä kivennäismailla tapahtuvissa mittauksissa, että teoreettisilla malleilla kolmion muotoisissa penkeissä $(\mathrm{h}=16 \mathrm{~cm}$, BENJAMIN ym. 1990), siniaallon mukaisissa penkeissä ( $h=25 \mathrm{~cm}$, RADKE 1982) ja myös melko suurissa pysyvän roudan alueella sijaitsevilla penkeissä ( $\mathrm{h}=15 \mathrm{~cm}$, SHARRRAT 1996). Penkit lisäävät ilman turbulenttista liikettä maan pinnassa (ALLMARAS ym.1977, ref. SHARRATT 1996), jolloin tuulisilla alueilla maan lämpötila voi penkeissä jäädä alemmaksi kuin tasaisella maalla ja penkit voivat kuivua liikaa lisääntyvän haihdunnan seurauksena.

Tässä esitettävät penkkiviljelytekniikan vaikutusta multa- ja turvemaiden lämpötilaan koskevat tutkimustulokset ovat osa lisensiaatintutkimusta, jonka tavoitteena oli selvittää penkkiviljelytekniikan soveltuvuutta ohran viljelyyn multa- ja turvemailla. Lämpötilan osalta tutkimushypoteesiksi muodostui: Penkkiviljelytekniikalla voidaan parantaa merkitsevästi maan lämpötilaoloja tasaiseen maahan nähden pohjoisilla multa- ja turvemailla.

\section{Aineisto ja menetelmät}

Kenttäkokeet järjestettiin Ilmajoella multamaalla vuosina 1999 - 2003. Tutkimuksessa oli kolme penkkikäsittelyä ja tasamaa verranteena (Kuvio 1). Koejärjestelynä oli satunnaistettujen lohkojen koe neljällä kerranteella. Kokeet perustettiin joka vuosi syyskynnetylle maalle. Koealue muokattiin $8-10 \mathrm{~cm}$ syvyyteen penkkien muotoilun helpottamiseksi. Koeruutujen bruttopituus vaihteli koekentästä ja vuodesta riippuen 16 - $17 \mathrm{~m}$ ja nettopituus vastaavasti $11-13 \mathrm{~m}$. Koeruudut tiivistettiin ennen kylvöä ja penkkien muotoilua 1,2 m leveällä kamrikkijyrällä (massa 300 kg). Penkkien muotoilu tapahtui kylvölannoittimen eteen ja taakse asetettujen muotoilulevyjen avulla. Tavoitekylvösyvyys oli $4 \mathrm{~cm}$. Lannoitesyvyys jätettiin matalaksi $(5 \mathrm{~cm})$, jotta penkit olisivat säilyttäneet muotonsa kylvön yhteydessä. Kaikkina vuosina täytyi penkkejä hieman muotoilla käsiharavalla kylvön jälkeen. Menettelyllä saatiin myös kaikkien käsittelyjen pinta samaan karkeusasteeseen, millä estettiin karkeuseron vaikutus energiabalanssiin (POTTER ym. 1987). 


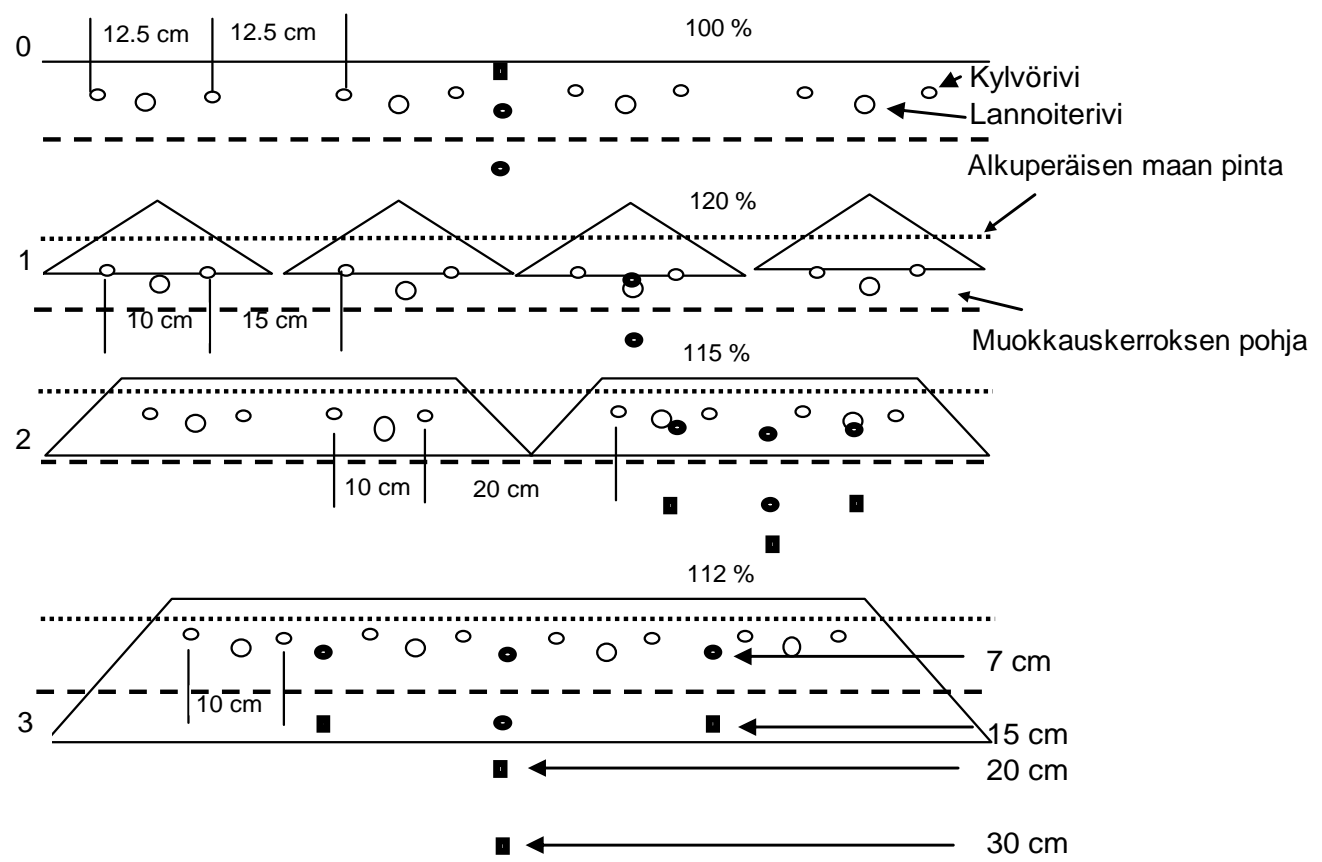

Kuvio 1. Tutkimuksen käsittelyt: 0 tasainen maa, 1 pieni kolmiopenkki (v. 1999 suuri kolmiopenkki, jossa 8 kylvöriviä), 2 pieni tasalakinen penkki ja 3 suuri tasalakinen penkki. Pienet avoimet ympyrät kuvaavat siemenrivejä, suuremmat lannoiterivejä ja tummat ympyrät ja neliöt lämpötilan mittauspisteitä. Kuvion prosenttiluku ilmaiseen maan kontaktipinta-alan ilmaan.

Lämpötilan mittauksissa käytettiin HP 34970A dataloggeria ja kolmea 20 kanavaista multiplekseriä. Antureina olivat $10 \mathrm{k} \Omega$ NTC termistorit, joiden mittausalue oli $0-70{ }^{\circ} \mathrm{C}$. Laitteisto säädettiin mittaamaan lämpötilat $20 \mathrm{~min}$ välein, mutta tulosten laskennassa ja esittämisessä kolmen mittauksen keskiarvo (tuntikeskiarvo) on pienin yksikkö. Anturit sijoitettiin ruudun keskelle 7 ja $15 \mathrm{~cm}$ syvyyteen ja sivuille (1/4 kohta, penkit 2 ja 3) $7 \mathrm{~cm}$ syvyyteen. Lisäksi käsittelyissä 3 ja 4 oli yksi anturi 20 ja $30 \mathrm{~cm}$ syvyydessä ja yksi anturi asetettiin mittaamaan ilman lämpötilaa 1,5 m korkeuteen.

Kosteudet määritettiin Trime FM-2 TDR-kosteusmittarilla käyttäen $11 \mathrm{~cm}$ pitkiä anturipiikkejä. Mittauskohta oli aina koeruudun tai penkin keskikohta. Käsittelyissä 3 ja 4 mitattiin lisäksi penkin kummankin reuna-alueen kosteus ns. $1 / 4$ kohdilta, jotka ovat samoja kuin kuvion 18 esittämät lämpötilan mittauspisteet. TDR-mittauksissa havainto on kahden mittauksen keskiarvo. Koska anturipiikki mittasi vain maan pintakerroksen kosteutta syvyysalueelta $0-11 \mathrm{~cm}$, mittaukset lopetettiin koekasvin ollessa selkeästi korrenkasvuvaiheessa.

Tuloksissa penkkikäsittelyistä mitattuja arvoja verrataan tasaiselta maalta saatuihin joko tuntikohtaisesti tai kasvukauden keskiarvoina. Tilastollinen käsittely on tehty SPSS for Windows 12.0.1 tilasto-ohjelmalla käyttäen varianssianalyysiä. Käsittelykeskiarvojen erojen merkitsevyyttä tutkittiin pareittain Dunnett’in kaksisuuntaisella testillä, jossa tasainen maa toimi verranteena.

\section{Tulokset ja tulosten tarkastelu}

Maan tuntikohtaisten lämpötilojen keskiarvo on kylvöhetkestä keltatuleentumisen ajankohtaan kestäneissä mittauksissa ollut penkkikäsittelyissä useimmiten hieman korkeampi kuin tasaisella maalla (Kuvio 1). Lämpötilaero penkkien hyväksi on myös poikkeuksetta ollut $15 \mathrm{~cm}$ syvyydessä suurempi kuin $7 \mathrm{~cm}$ syvyydessä. Penkkityyppien välillä ei juuri ole eroa. Samoin vuosien väliset erot jäävät vähäisiksi. Anturien vähäisestä määrästä ja maan ominaisuuksien vaihtelusta johtuvan hajonnan vuoksi käsittelyjen väliset lämpötilaerot eivät juurikaan ole tilastollisesti merkitseviä. Vuoden 1999 tulokset poikkeavat yleisestä linjasta. Kokonaissademäärältään vähäsateisena kesänä v. 1999 oli kuitenkin runsaasti pieniä sadekuuroja, jolloin maan pinta on ollut kostea suuren osan kesästä. Lisäksi kesä oli melko tuulinen, jolloin penkeistä on ilmeisesti haihtunut tasaista maata enemmän vettä, mikä on pitänyt ne viileämpänä kuin tasainen maa. Anturien pieni määrä (15 cm syvyydessä kaksi anturia) lisää myös satunnaisvirheen mahdollisuutta. Taulukon 1 kanssa samansuuntaisia tuloksia ovat monivuotisissa massipenkeissä mitanneet mm. SPOOR ja GILES, (1973), tasatulokseen ovat päätyneet STONE ym. (1989) sekä KOVAR ym. (1992) 
ja tasainen maa on ollut lämpimämpi SHARRATIN (1996) pysyvän roudan alueella suorittamissa tutkimuksissa. Lähinnä tämän tutkimuksen penkkimuotoa on ollut BENJAMIN ym. (1990) tutkimuksissaan, joissa tavanomainen maissin viljelyssä käytetty penkki puristettiin keskeltä matalaksi muodoltaan lähelle tämän tutkimuksen suurta tasalakista penkkiä. Käsittelyn vaikutuksesta penkin keskilämpötila nousi n. yhden asteen korkeammaksi kuin ilman käsittelyä jääneen penkin lämpötila.

Taulukko 1. Tuntikohtaisten lämpöilojen keskiarvot 7 ja 15 cm syvyydessä kylvön ja keltatuleentumisen väliseltä ajalta Munakan kokeessa. Penkkikäsittelyjen lämpötilat on ilmaistu lämpötilaerona tasaiseen maahan nähden. Taulukossa on myös muutama lämpötilatulos 20 ja $30 \mathrm{~cm}$ syvyydeltä.

\begin{tabular}{|c|c|c|c|c|c|c|c|}
\hline \multirow[b]{3}{*}{ Vuosi } & \multicolumn{7}{|c|}{ Maan lämpötila } \\
\hline & \multirow[b]{2}{*}{ Käsittely } & \multicolumn{2}{|c|}{$7 \mathrm{~cm}$} & \multicolumn{2}{|c|}{$15 \mathrm{~cm}$} & \multirow{2}{*}{$\begin{array}{c}20 \mathrm{~cm} \\
{ }^{\circ} \mathrm{C} \\
\end{array}$} & \multirow{2}{*}{$\begin{array}{c}30 \mathrm{~cm} \\
{ }^{\circ} \mathrm{C} \\
\end{array}$} \\
\hline & & ${ }^{\circ} \mathrm{C}$ & $\mathrm{p}$ & ${ }^{\circ} \mathrm{C}$ & $\mathrm{p}$ & & \\
\hline \multirow[t]{4}{*}{1999} & 0 & 15,54 & & 14,27 & & & \\
\hline & 1 & $-0,13$ & & 0,28 & & & \\
\hline & 2 & $-0,12$ & & 0,22 & & & \\
\hline & 3 & $-0,21$ & & $-0,25$ & & & \\
\hline \multirow[t]{4}{*}{2001} & 0 & 14,39 & & 13,37 & & & \\
\hline & 1 & $-0,01$ & & 0,42 & $*$ & & \\
\hline & 2 & 0,04 & & 0,08 & & & \\
\hline & 3 & 0,22 & & 0,21 & & & \\
\hline \multirow[t]{4}{*}{2002} & 0 & 16,09 & & 14,80 & & & \\
\hline & 1 & 0,25 & & 0,32 & & & \\
\hline & 2 & 0,33 & & 0,49 & 0 & 15,1 & 13,8 \\
\hline & 3 & 0,28 & & 0,34 & & 14,4 & 12,8 \\
\hline \multirow[t]{4}{*}{2003} & 0 & 15,25 & & 14,06 & & & \\
\hline & 1 & 0,07 & & 0,33 & & & \\
\hline & 2 & 0,07 & & 0,21 & & 13,5 & 12,5 \\
\hline & 3 & 0,12 & & 0,29 & & 13,7 & 12,5 \\
\hline
\end{tabular}

Lämpötila-aineisto antaa myös viitteitä, että penkkien lämpötilaerot tasaiseen maahan nähden riippuvat sääoloista (Kuvio 2, suuri tasalakinen penkki v. 2001). Selvästi keskiarvoa lämpimämpien kausien aikana penkkien lämpötila on kohonnut tasaisen maan lämpötilaa korkeammaksi. Samalla myös penkkien lämpötilan vuorokausivaihtelu suhteessa tasaisen maan vaihteluun on kasvanut suuremmaksi kuin viileämmillä jaksoilla. Havainnon pohjalta on taulukkoon 2 koottu vuosilta 2001 ja 2003 neljä sääoloiltaa erilaista viikkoa tarkempaa analyysiä varten. Ensimmäiset viikot ovat ennen orastumista, toiset orasvaiheen ajalta, kolmannet korrenkasvun ajalta ja viimeiset ajalta, jolloin ohra oli jo tähkällä. Valituista viikoista kaksi ensimmäistä molempina vuosina ovat olleet viileitä ja toinen molempina vuosina on ollut vähäsateinen. Kolmansien viikkojen ilman keskilämpötilat ovat olleet lähellä kyseisen ajanjakson keskiarvolämpötiloja. Neljäs viikko oli molempina vuosina selvästi tavanomaista lämpimämpi ja sateet jäivät vähäisiksi.

Penkkien lämpötila nousee selvimmin tasaisen maan lämpötiloja suuremmaksi, jos aurinkoinen ja lämmin sää ajoittuu kasvukauden alkuun (esim. v. 2002). Penkkien suurempi pinnan ala ja erityisesti pinnan suotuisa kulma tulosäteisiin nähden tehostaa lämmön siirtymistä maahan. Näin käy selkeimmin aamulla ja iltapäivällä, jolloin aurinko on paistanut penkkien sivuihin (penkkien suunta kaakko-luode). Kun matalalla oleva aurinko paistaa penkin sivuun tasaisen pinnan sijaan, heijastuu tulevasta säteilystä huomattavasti vähäisempi määrä (HOUGHTON 1954, ref. BAVER ym. 1972). Myös myöhemmin kasvukaudella lämpimät säät näkyvät penkkien ja tasaisen maan lämpötilaeroissa (Taulukko 2). Lämpimien säiden vallitessa heinäkuussa tutkimusvuosina 2001 - 2003, ovat erot olleet $0,2-0,7^{\circ} \mathrm{C}$ penkkikäsittelyjen eduksi. 


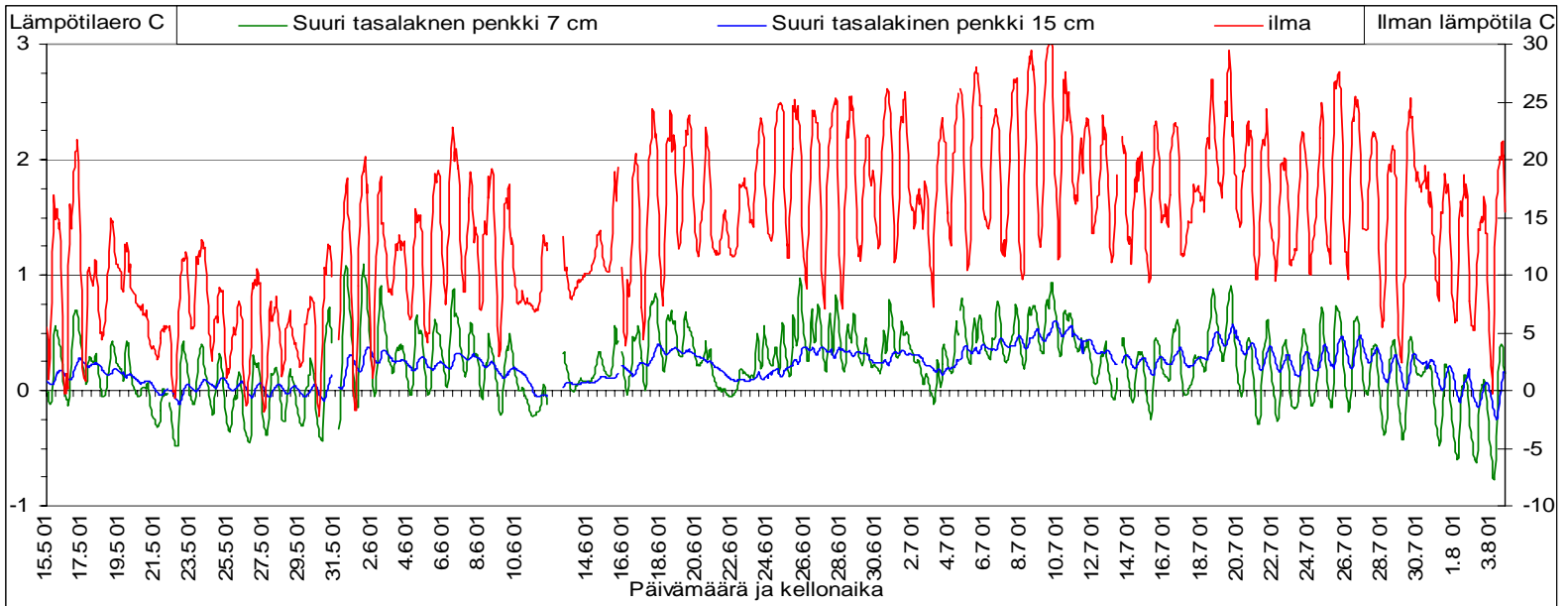

Kuvio 2. Maan lämpötilan tuntikeskiarvojen erotus suuressa tasalakisessa penkissä tasaisen maan lämpötilasta 7 ja 15 cm syvyydessä, v. 2001 Munakka.

Pitkästä kasvustosta huolimatta penkeissä jää vaon kohdalle normaalia riviväliä suurempi kasvustosta vapaa alue, johon auringon suora säteily on voinut vaikuttaa osan aikaa keskipäivästä. Kasvusto vähentää myös maan karkeusasteesta (penkeistä) johtuvaa maan lämpötilaa alentavaa ilman turbulenttista virtailua (POTTER 1987).

Myös viileällä ja kuivalla säällä maan lämpötila on ollut penkeissä korkeampi kuin tasaisessa maassa, mutta erot ovat pienempiä kuin lämpimillä jaksoilla. Sen sijaan viileällä ja sateisella säällä penkkien lämpötilat ovat lähellä tasaisen maan lämpötiloja. Yhtä poikkeusta lukuun ottamatta ne ovat silti olleet korkeampia kuin tasaisessa maassa. Näillä viileillä kausilla, jolloin penkkien lämpötilaetu olisi ollut eniten tarpeen, on se

Taulukko 2. Neljän säätilaltaan erilaisen seitsemän päivän jakson tuntikohtaisten lämpötilojen keskiarvot Munakan kokeissa v. 2001 ja 2003. Jaksot ovat vuosittain: 1. 15-23.5 ja 30.5-5.6, 2. 1-7.6 ja 9-15.6, 3. 16-22.6 ja 23-29.6, 4. 511.7 ja 16-23.7. Taulukossa on myös laskentaviikon ilman tuntikohtaisten lämpötilojen keskiarvo ja laskentaviikon ja sitä edeltävän viikon sadesumma. Käsittelyt: 0 = tasainen maa, 1= pieni kolmiopenkki, 2 = pieni tasalakinen penkki ja 3 = suuri tasalakinen penkki.

\begin{tabular}{|c|c|c|c|c|c|c|c|c|c|c|c|c|c|}
\hline \multirow{4}{*}{$\begin{array}{c}\text { Jaks } \\
0\end{array}$} & \multicolumn{7}{|c|}{2001} & \multicolumn{6}{|c|}{2003} \\
\hline & \multirow{2}{*}{$\begin{array}{l}\text { Ilman } \\
\text { lämpö }\end{array}$} & \multirow[b]{2}{*}{ Sade } & \multirow{3}{*}{$\begin{array}{c}\text { Käsit } \\
\text { tely }\end{array}$} & \multicolumn{4}{|c|}{ Maan lämpötila } & \multirow{2}{*}{$\begin{array}{l}\text { Ilman } \\
\text { lämpö }\end{array}$} & \multirow{3}{*}{$\frac{\text { Sade }}{\mathrm{mm}}$} & \multicolumn{4}{|c|}{ Maan lämpötila } \\
\hline & & & & \multicolumn{2}{|c|}{$7 \mathrm{~cm}$} & \multicolumn{2}{|c|}{$15 \mathrm{~cm}$} & & & \multicolumn{2}{|c|}{$7 \mathrm{~cm}$} & \multicolumn{2}{|c|}{$15 \mathrm{~cm}$} \\
\hline & ${ }^{\circ} \mathrm{C}$ & $\mathrm{mm}$ & & ${ }^{\circ} \mathrm{C}$ & $\mathrm{p}$ & ${ }^{\circ} \mathrm{C}$ & $\mathrm{p}$ & ${ }^{\circ} \mathrm{C}$ & & ${ }^{\circ} \mathrm{C}$ & $\mathrm{p}$ & ${ }^{\circ} \mathrm{C}$ & $\mathrm{p}$ \\
\hline \multirow[b]{5}{*}{1.} & \multirow[b]{5}{*}{7,8} & \multirow[b]{5}{*}{52} & 0 & 9,21 & & 8,66 & & \multirow[b]{5}{*}{12,1} & \multirow[b]{5}{*}{13} & 12,34 & & 10,88 & \\
\hline & & & 1 & $-0,02$ & & 0,20 & * & & & 0,24 & 0 & 0,33 & \\
\hline & & & 2 & 0,04 & & 0,09 & & & & 0,03 & & 0,23 & \\
\hline & & & 3 & 0,07 & & 0,08 & & & & 0,12 & & 0,29 & \\
\hline & & & & & & & & & & & & & \\
\hline \multirow[b]{5}{*}{2.} & \multirow[b]{5}{*}{12,4} & \multirow[b]{5}{*}{7} & 0 & 13,24 & & 11,61 & & \multirow[b]{5}{*}{11,1} & \multirow[b]{5}{*}{66} & 13,44 & & 12,53 & \\
\hline & & & 1 & 0,16 & & 0,42 & ** & & & 0,13 & & 0,22 & \\
\hline & & & 2 & 0,10 & & 0,14 & & & & $-0,12$ & & 0,05 & \\
\hline & & & 3 & 0,36 & $* *$ & 0,26 & & & & 0,14 & & 0,26 & \\
\hline & & & & & & & & & & & & & \\
\hline \multirow[b]{5}{*}{3.} & \multirow[b]{5}{*}{15,6} & \multirow[b]{5}{*}{61} & 0 & 15,62 & & 14,19 & & \multirow[b]{5}{*}{15,9} & \multirow[b]{5}{*}{9} & 16,45 & & 14,93 & \\
\hline & & & 1 & 0,49 & $* *$ & 0,74 & $* *$ & & & 0,05 & & 0,28 & \\
\hline & & & 2 & 0,33 & $*$ & 0,22 & & & & $-0,01$ & & 0,18 & \\
\hline & & & 3 & 0,29 & 0 & 0,23 & & & & $-0,29$ & & $-0,06$ & \\
\hline & & & & & & & & & & & & & \\
\hline \multirow[b]{4}{*}{4.} & \multirow[b]{4}{*}{20,6} & & 0 & 18,26 & & 16,74 & & & & 19,42 & & 17,80 & \\
\hline & & & 1 & 0,09 & & 0,71 & * & & & 0,16 & & 0,61 & 0 \\
\hline & & & 2 & 0,21 & & 0,13 & & & & 0,25 & $*$ & 0,52 & \\
\hline & & 4 & 3 & 0,48 & * & 0,43 & & 22,5 & 21 & 0,38 & ** & 0,62 & 0 \\
\hline
\end{tabular}


jäänyt alhaisimmaksi. Tulevasta säteilystä kuluu tällöin suuri osa veden haihduttamiseen. Penkkien $12-20$ \% suurempi pinta-ala mahdollistaa sateen jälkeen tasaista maata tehokkaamman veden haihtumisen. Tuulinen sää vielä tehostaa haihtumista. Myös pilvisellä säällä lämpötilaerot jäävät pieniksi, koska tulosäteilyn taso on alhainen, mutta suuremman pinta-alansa vuoksi penkit voivat luovuttaa pitkäaaltoista lämpösäteilyä tasaista maata enemmän. Runsaiden sateiden jälkeen maan lämmönjohtavuus on ilmeisesti lisääntynyt niin paljon, että seuraavien lämpimien kausien aikana maan lämpötilan vuorokausivaihtelu 7 ja $15 \mathrm{~cm}$ syvyydellä on ollut suurempaa, verrattuna kuivien kausien lämpimiin jaksoihin. Tällöin maan lämpötila on penkeissä ajoittain laskenut keskellä päivää tasaisen maan lämpötiloja alemmaksi (jakso 3 v. 2003). Samalla myös penkkien lämpötila on vaihdellut enemmän tasaiseen maahan nähden. Penkkien suuremman lämpötilavaihtelun on todennut mm. RADGE (1982). Suurempi haihdutus kuivattaa penkit tasaista maata nopeammin, jolloin lämpötila on pitkän poutakauden tullessa noussut penkeissä tasaista maata korkeammaksi (jakso 4 v. 2003).

\section{Johtopäätökset}

Penkkien lämpötilojen samankaltainen poikkeama tasaisen maan lukemista useana vuonna on vahva näyttö penkkikäsittelyn hypoteesin mukaisesta vaikutuksesta, vaikka tilastollinen merkitsevyys jääkin vähäiseksi. Kun kasvien kasvuprosessien $\mathrm{Q}_{10}$ arvo selvästi kasvin optimilämpötiloja viileämmissä olosuhteissa on yleensä n. 2 (TING 1981, AMTHOR 1989), vastaa 0,2 - 0,4 ${ }^{\circ} \mathrm{C}$ lämpötilan muutosta $2-4$ prosenttiyksikön kasvun muutos. Tämän vuoksi jää mitatun lämpötilaedun käytännön merkitys pieneksi, joten asetettu hypoteesi joudutaan hylkäämään..

Tässä tutkimuksessa maata ei normaalista poiketen tiivistetty (jyrätty) kylvön jälkeen. Tällöin on mahdollista, että erityisesti pieni kolmiopenkki on jäänyt löyhemmäksi kuin tasainen maa, jonka seurauksena lämpöetu ei ole tullut täysimääräisesti näkyviin. Tämän selvittämiseksi tiivistämiskäsittely tulisi olla mukana mahdollisissa lisätutkimuksissa.

\section{Kirjallisuus}

Allmaras, R. R. Hallauer, E .A. Nelson, W. W. \& Evans, S. D. 1977. Surface energy balance and soil thermal property modifications by tillage-induced soil structure. Minnesota Agricultural Experimental Station Technical Bulletin 306. Ref. Sharrat, B., S. 1996. Soil Temperature, Water Content, and Barley Development of Level vs. Ridged Subarctic Seedbeds. Soil Science Society of America Journal 60:258-263

Amthor, J. S. 1989. Respiration and Crop Productivity. Springer-Verlag. New York. 215 p.

Benjamin, J. B, Ghaffarzadeh, M. R. \& Cruse, R. M. 1990. Coupled Water and Heat Transport in Ridged Soils. Soil Science Society of America Journal 54:963-969.

Duin, R. H. A. van 1963. The Influence of Soil Management on the Temperature Wave near the Soil Surface. Institution for Land and Water Management Research. Technical Bulletin 29. Ref. Baver, L. D., Gardner, W. H. \& Gardner, W. R. 1972. Soil physics. Fourth edition. John Wiley \& sons. New York. 492 p

Feddes, R. A. 1972. Effects of Water and Heat on Seedling Emergence. Journal of Hydrology 16:341-359.

Feddes, R. A. 1973. Some Physical Aspects of Heat Transfer in Soils. Acta Horticulture 27:189-194.

Hanks, R. J. 1992. Applied Soil Physics. New York, USA. 176 p.

Houghton, H. G. 1954. On the annual heat balance of the Northern Hemisphere. Journal of Meteorology 11:1-9. Ref. Baver, L. D., Gardner, W. H. \& Gardner, W. R. 1972. Soil physics. Fourth edition. John Wiley \& sons. New York. $492 \mathrm{p}$.

Kovar, J. L., Barber, S., Kladivko, E. J. \& Griffith, D. R. 1992. Characterization of Soil Temperature, Water Content, and Maize Root Distribution in two Tillage Systems. Soil \& Tillage Research 24:11-27.

Liepiec, J., Håkansson, I., Tarkiewicz, S. \& Kossowski, J. 1991. Soil physical properties and growth of spring barley as related to the degree of compactness of two soils. Soil \& Tillage Research 19:307-317.

Mayer, A. M \& Poljakoff-Mayer, A. 1989. The germination of seeds. Oxford. 270 p.

Myllys \& Sinkkonen, M. 2004. Viljeltyjen turve- ja multamaiden pinta-ala ja alueellinen jakauma Suomessa. Suo 55(3-4):53-60.

Potter, K. N., Cruse, R. M. \& Horton, R. 1985. Tillage Effects on Soil Thermal

Properties. Soil Science Society of America Journal 49:968-97.

Potter, K. N., HORTON, R. \& CRUSE, R. M. 1987. Soil Surface Roughness Effects on

Radiation Reflectance and Soil Heat Flux. Soil Science Society America Journal 51:855-860.

Radke, J. K. 1982. Managing Early Season Soil Temperatures in the Northern Corn Belt

Using Configured Soil Surfaces and Mulches. Soil Science Society of America Journal 46:1067-1071. 
Sharrat, B.S. 1996. Soil Temperature, Water Content, and Barley Development of Level vs. Ridged Subarctic Seedbeds. Soil Science Society of Am. J. 60:258-263.

Spoor, G. \& Giles, D. F. H. 1973. Effects of Cultivations on Rising Spring Soil Temperatures for Germination with Particular Reference to Maize. Journal of Soil Science 24:392-398.

Stone, J. A., Vyn, T. J., Martin, H. D. Groenevelt, P. H. 1989. Ridge-Tillage and Early-Season Soil Moisture and Temperature on a Poorly Drained soil. Canadian Joournal of Soil Science 69:181-186

Ting, I. P. 1982. Plant Physiology. Addison-Wesley Publishing Company. California. 642 p.

Ylihalla, M. 1998. Soil Temperature Regime in Finland. Agricultural and Food Science in Finland 7:507-512. 